\title{
CAMPUR KODE DALAM KOMUNIKASI BAHASA ARAB SANTRI PONDOK MODERN MADINAH LAMPUNG TIMUR (KAJIAN SOSIOLINGUISTIK)
}

\author{
Nur Fauziah Fatawi \\ ucizikria@gmail.com
}

\begin{abstract}
This research discusses about the phenomena of blended code in Arabic conversation of students of Madinah Modern Islamic Boarding School. This phenomena happen because a majority of students in saying Arabic are still influenced by local language and less balance in mastering two languages. So that, often happening deviation and appearing language case names mingled code. Related with the gotten blended code data, the researcher uses blended code theory filed by Muysken for analyzing the data. There are three blended cose by Muysken are insertion, alternation, and congruent lexicalization. The method which is used in this research are observation and interview method. First: observation method, this method has base technique. It is a skillful involved free observed technique note, and record. Second: interview method, at interview method applied by inducement technique, this technique is used as base technique and record technique as continuing technique. The objective of this research is to identify mingled code in Arabic conversation of students of Madinah Boarding School, local language elements in Arabic.
\end{abstract}

Keywords: a mingled code, bilingual, Muysken, Insertion, alternation, congruent lexicalization

\begin{abstract}
Abstrak
Penelitian ini membahas tentang fenomena campur kode dalam percakapan bahasa Arab santri Pondok Modern Madinah. Fenomena ini terjadi karena mayoritas santri dalam melafalkan bahasa Arab, tidak dapat lepas dari pengaruh bahasa lokal dan kurang seimbang dalam penguasaan dua bahasa, sehingga seringkali terjadi penyimpangan dan memunculkan fenomena kebahasaan yaitu campur kode. Terkait dengan data campur kode yang diperoleh, peneliti menggunakan teori campur kode yang diajukan oleh Muysken untuk analisis data. Adapun tiga wujud campur kode yang diajukan Muysken diantaranya, insertion (penyisipan), alternation (alternasi) dan congruent lexicalization (leksikalisasi kongruen). Metode yang digunakan dalam penelitian ini adalah metode simak (pengamatan/observasi) dan metode cakap (wawancara). Pertama; metode simak, pada metode ini memiliki teknik dasar yaitu teknik sadap, Sebagai teknik dasar maka ia mengalami teknik lanjutan yaitu teknik simak bebas libat cakap, teknik simak libat cakap, catat, dan rekam. Kedua: metode cakap (wawancara), dalam metode cakap diterapkan dengan teknik pancing, teknik ini digunakan sebagai teknik dasar dan teknik rekam sebagai teknik lanjutan.Penelitian ini bertujuan untuk mengidentifikasi wujud-wujud campur kode yang terdapat dalam percakapan bahasa Arab santri Pondok Madinah, dan unsur-unsur bahasa lokal yang masuk dalam bahasa Arab.
\end{abstract}

Kata Kunci: Campur kode, bilingual, Muysken, penyisipan, alternasi, leksikalisasi kongruen 


\section{Pendahuluan}

Bahasa merupakan sarana interaksi dan komunikasi bagi manusia. Dalam peristiwa komunikasi, alat yang digunakan adalah bahasa (sebagai sistem lambang), tanda-tanda (baik berupa gambar, warna, ataupun bunyi), dan gerak tubuh. Berdasarkan alat yang digunakan ini dibedakan atas dua macam komunikasi, yaitu verbal dan nonverbal. komunikasi verbal yaitu menggunakan bahasa sebagai alatnya. Sedangkan komunikasi nonverbal yaitu menggunakan alat bukan bahasa, seperti bunyi peluit, cahaya, semafor, dan termasuk alat komunikasi pada masyarakat hewan. Sebagai alat komunikasi manusia, bahasa adalah suatu sistem yang bersifat sistematis dan sekaligus sistemis. Dikatakan sistemis karena bahasa itu bukan suatu sistem tunggal melainkan terdiri juga dari beberapa subsistem, yaitu subsistem fonologi, morfologi, sintaksis, semantik. ${ }^{2}$

Manusia adalah makhluk sosial yang tidak dapat lepas dari interaksi dan komunikasi kepada sesama diberbagai aktifitasnya sehari-hari, untuk itu bahasa memegang peranan penting sebagai sarana komunikasi yang kompleks. Adapun fenomena yang sering kita jumpai dalam masyarakat yaitu penggunaan bahasa yang

\footnotetext{
${ }^{1}$ Abdul Chaer Leonie Agustina, Sosiolinguistik Perkenalan Awal Edisi Revisi Cet Kedua, Rineka Cipta, Jakarta: 2004, h. 19-20

${ }^{2}$ Abdul Chaer, Linguistik Umum Cet Ketiga, (Jakarta 2007, Rineka Cipta) h. 4.
}

beragam dan berbeda sesuai dengan latar belakang masing-masing baik kultural, pendidikan, maupun profesi. dengan masyarakat yang memiliki beragam kultur sehingga memilki bahasa yang beragam pula, dari sinilah bisa dilihat fenomena dwibahasa atau bahkan anekabahasa. Kondisi seperti ini yang menyebabkan masyarakat memakai dua bahasa (bilingualism) dan aneka bahasa (multilingualism) yang dapat memunculkan peristiwa campur kode (code mixing). Dapat dipahami secara sederhana, bahwa peristiwa campur kode ialah ketika seseorang menyelipkan unsur-unsur bahasa lain (Jawa) kedalam Bahasa yang digunakan (Bahasa Arab).

Campur kode adalah termasuk kajian kebahasaan di dalam masyarakat, sedangkan ilmu yang mempelajari kajian kebahasaan didalam masyarakat adalah sosiolinguistik. Sosiolinguistik sebagai cabang linguistik memandang atau menempatkan kedudukan bahasa dalam hubungannya dengan pemakai bahasa didalam masyarakat, karena dalam kehidupan bermasyarakat manusia tidak lagi sebagai individu, akan tetapi sebagai masyarakat sosial. ${ }^{3}$ Masyarakat yang multilingual memungkinkan adanya kontak bahasa dari masing-masing bahasa yang bisa terjadi dimana saja, salah satunya yaitu di lingkungan Pendidikan. Di lingkungan

\footnotetext{
${ }^{3}$ Dewa Putu Wijana Dan Muhammad Rohmadi, Sosiolinguistik, Cetakan Iv,(Yogyakarta:2012, Pustaka Pelajar) h. 7
} 
pendidikan pasti akan mengalami fenomena ini, karena para siswa yang berada di lembaga tidak hanya dari satu bahasa saja melainkan dari berbagai bahasa, sehingga sangat memungkinkan adanya kontak bahasa dari masing-masing bahasa, dan salah satu lembaga pendidikan yang mengalami hal serupa adalah Pondok Pesantren. Pondok pesantren adalah salah satu lembaga pendidikan yang sangat intens sistemnya sebagai wadah kontak bahasa. Karena masyarakat di pesantren terdiri dari masyarakat yang multilingual sehingga dengan keberadaannya para santri yang multilingual mengakibatkan munculnya beberapa fenomena kebahasaan salah satunya adalah campur kodeyang akan menjadi topik pembahasan dalam penelitian ini.

Dalam hal ini peneliti akan membahas sekaligus mengkaji dari aspek campur kode dikalangan santri Pondok Madinah Lampung Timur.Terkait dengan data campur kode yang diperoleh, peneliti menggunakan teori Muysken untuk menganalisis fenomena tersebut, karena teori campur kode yang diajukan Muysken sesuai untuk kajian campur kode dalam percakapan bahasa Arab santri Pondok Madinah. Tiga bentuk campur kode yang diajukan Muysken adalah, insertion (penyisipan), alternation (alternasi) dan congruent lexicalization (leksikalisasi kongruen).

\section{Pembahasan}

\section{Kontak Bahasa}

Kontak bahasa adalah saling pengaruh antara pelbagai bahasa karena para penuturnya sering bertemu. ${ }^{4}$ Dapat dipahami bahwa kontak bahasa merupakan sebuah peristiwa dimana seseorang pengguna lebih dari satu bahasa saling berkomunikasi. Dalam masyarakat yang terbuka, artinya yang para anggotanya dapat menerima kedatangan anggota dari masyarakat lain, baik dari satu atau lebih dari satu masyarakat, akan terjadilah apa yang disebut dengan kontak bahasa. bahasa dari satu masyarakat ke masyarakat yang lain akan saling mempengaruhi. Dengan adanya kontak bahasa inilah akan mendapati masyarakat bilingual atau multilingual yang akan memunculkan beberapa kasus kebahasaan salah satunya adalah kasus tentang campur kode. ${ }^{5}$

\section{Bilingualisme}

Istilah bilingualisme dalam bahasa Indonesia disebut juga kedwibahasaan. Istilah ini dapat dipahami yaitu berkenaan dengan penggunaan dua bahasa atau dua kode bahasa. Secara sosiolinguistik maupun secara umum, diartikan sebagai penggunaan dua bahasa oleh seorang penutur dalam pergaulannya dengan orang lain secara bergantian. Untuk dapat menggunakan dua

\footnotetext{
${ }^{4}$ Departemen Pendidikan dan Kebudayaan, Kamus Besar Bahasa Indonesia (Kbbi) Cet Ix, (Jakarta:1997, Balai Pustaka), h. 521

${ }^{5}$ Abdul Chaer, Linguistik Umum Cet Ketiga, (Jakarta 2007, Rineka Cipta) h. 65
} 
bahasa tentunya seseorang harus menguasai kedua bahasa itu, pertama bahasa ibunya sendiri atau bahasa pertama (B1) dan yang kedua bahasa lain yang menjadi bahasa kedua (B2). Menggunakan kedua bahasa itu disebut orang yang bilingual (dalam bahasa Indonesia juga disebut dwibahasawan). ${ }^{6}$ Jadi dapat dibedakan, jika "kedwibahasaan adalah perihal pemakaian dua bahasa" sedangkan "dwibahasawan adalah orang yang dapat berbicara dalam dua bahasa". 7

Selain ada istilah bilingualisme yaitu yang berarti pengguna dua bahasa, ada juga istilah multilingualisme dalam bahasa Indonesia disebut jua keanekabahasaan yaitu berarti pengguna lebih dari dua bahasa ketika berkomunikasi dengan orang lain secara bergantian. ${ }^{8}$ Sebagaimana dalam Kamus Besar Bahasa Indonesia, multi; banyak atau lebih dari satu, lebih dari dua. Multi bahasa; lebih dari sau bahasa, kemampuan menggunakan beberapa bahasa dalam komunikasi, sedangkan multibahasawan orang yang mampu menggunakan berbagai berbagai bahasa. ${ }^{9}$

\footnotetext{
${ }^{6}$ Abdul Chaer Leonie Agustina, Sosiolinguistik Perkenalan Awal Edisi Revisi Cet Kedua, Rineka Cipta, Jakarta: 2004, h. 84

${ }^{7}$ Henry Guntur Tarigan, Pengajaran Kedwibahasaan, (Bandung:2009, Angkasa), h. 3

${ }^{8}$ Ibid, Hal 85.ff

${ }^{9}$ Departemen Pendidikan Dan Kebudayaan, Kamus Besar Bahasa Indonesia (Kbbi) Cet Ix, (Jakarta:1997, Balai Pustaka), h. 671
}

\section{Campur Kode (code mixing)}

Ada beberapa definisi tentang Kode. Menurut Kridalaksana Kode adalah lambang atau sistem ungkapan yang dipakai untuk menggambarkan makna tertentu. Bahasa manusia adalah sejenis kode;. Sistem bahasa dalam suatu masyarakat; Variasi tertentu dalam suatu bahasa. ${ }^{10}$ Kode adalah istilah netral yang dapat mengacu kepada bahasa, dialek, sosiolek, atau ragam bahasa. ${ }^{11}$

Menurut kamus linguistik, campur kode (code mixing) ialah interferensi, atau penggunaan satuan bahasa dari satu bahasa ke bahasa lain untuk memperluas gaya bahasa atau ragam bahasa, termasuk di dalamnya pemakaian kata, klausa, idiom, sapaan dsb. ${ }^{12}$ Campur kode memiliki definisi dari beberapa ahli, seorang ahli menjelaskan, campur kode adalah penggunaan dua bahasa atau lebih atau ragam bahasa secara santai antara orang-orang yang kita kenal dengan akrab. Ahli lain menjelaskan bahwa campur kode mengacu pada suatu peristiwa pentur mencampur dua (atau lebih) bahasa atau ragam bahasa dalam suatu tindak bahasa (speech act atau discourse) tanpa ada sesuatu dalam situasi berbahasa itu yang menuntut percampuran bahasa itu. Kridalaksana menjelaskan bahwa campur kode antara lain

\footnotetext{
${ }^{10}$ Harimurti Kridalaksana, Kamus Linguistik Edisi Ketiga (Jakarta: Gramedia Pustaka Utama: 2001), h. 113

${ }^{11}$ Sumarsono, Sosiolinguistik Cetakan Ix, Pustaka Pelajar Sabda, Yogyakarta:2013, h. 201

${ }^{12}$ Harimurti Kridalaksana, Kamus Linguistik Edisi Ketiga (Jakarta: Gramedia Pustaka Utama: 2001), h. 35
} 
berati penggunaan suatu bahasa dari satu bahasa ke bahasa lain untuk memperluas gaya, dan ragam bahasa, termasuk di dalamnya pemakaian kata, klausa, idiom, sapaan dan sebagainya. ${ }^{13}$

Campur kode adalah suatu keadaan berbahasa bilamana orang mencampur dua atau lebih bahasa dengan saling memasukkan unsur-unsur bahasa yang satu ke dalam bahasa yang lain, unsur-unsur yang menyisip tersebut tidak lagi mempunyai fungsi sendiri. Sebagaimana hal tersebut campur kode memiliki berbagai macam bentuk diantaranya adalah campur kode berwujud kata, kata ulang, kelompok kata, frase, idiom, maupun klausa. ${ }^{14}$

Muysken menggunakan istilah campur kode, karena lebih netral dan tidak membuat klaim tentang mekanisme yang terkandung di dalamnya. Campur kode mengimplikasikan sebagai hasil dari ujaran yang spontan. Hatch menggunakan terminologi 'campur kode' untuk mengacu fenomena lain yang terkait seperti serapan (borrowing), interferensi, transfer ataupun peralihan. $^{15}$

Muysken mengajukan 3 bentuk campur kode pertama; (insertion)

\footnotetext{
${ }^{13}$ Sarwiji Suwandi, Serbalinguistik Mengupas Pelbagai Praktik Bahasa Cetakan I, Lpp Uns Dan Uns Press. Surakarta:2008, h. 87

${ }^{14}$ Dewa Putu Wijana Dan Muhammad Rohmadi, Sosiolinguistik, Cetakan Iv, (Yogyakarta:2012, Pustaka Pelajar, h. 171

${ }^{15}$ Annisa Ramadhani, Campur Kode Bahasa Indonesia-Bahasa Inggris Dalam Acara Welcome To Bca Di Metro Tv, Fib Ui, Jakarta: 2011, h. 16
}

penyisipan, kedua;(alternation) alternasi dan ketiga;(congruent lexicalization) leksikalisasi kongruen. Tiga hal campur kode tersebut memiliki proses yang berbeda di antaranya:

- Penyisipan (beberapa leksikal atau seluruh konstituen) dari satu bahasa ke dalam struktur bahasa lain.

- Alternasi diantara beberapa struktur dari beberapa bahasa.

- Leksikalisasi kongruen dari leksikal yang berbeda dalam struktur yang sama. ${ }^{16}$

\section{a. Penyisipan(insertion)}

Unsur-unsur yang dimasukkan dalam bentuk campur kode penyisipan, adalah berupa konstituen, yang mana konstituen tersebut berupa unit sintaksis berbentuk kata dan frasa. Penyisipan yang memasukkan elemen tunggal disebut well-defined. Ada juga beberapa kasus yang memasukan beberapa konstituen dalam satu tuturan sehingga disebut penyisipan konstituen ganda berdampingan. Selain kedua fitur tersebut ada satu fitur lain yang masuk pada penyisipan, yaitu konstituen yang terintegrasi secara morfologis. ${ }^{17}$

\section{b. Alternasi (alternation)}

Bentuk campur kode yang kedua adalah alternasi, dalam alternasi terjadi peralihan beberapa konstituen dalam satu

\footnotetext{
${ }^{16}$ Pieter Muysken, Muysken, Bilingual Speech A Typology Of Code Mixing, Cambridge University Press,Cambridge:2000, h. 3

${ }^{17}$ Annisa Ramadhani, Campur Kode Bahasa Indonesia-Bahasa Inggris Dalam Acara Welcome To Bca Di Metro Tv, Fib Ui, Jakarta: 2011, h. 21
} 
ujaran karena penutur mengalihkan bahasa maupun ragam secara bersamaan. Bentuk campur kode alternasi berupa rangkaian yang dialihkan yang diawali dan diikuti oleh elemen bahasa lain yang mana elemen-elemen tersebut tidak terhubung secara struktural, bentuk seperti ini dapat disebut dengan alternasi. Alternasi memiliki dua fitur yaitu penandaan (flagging) dan penggandaan (doubling). ${ }^{18}$

\section{c. Leksikalisasi kongruen (congruent lexicalization)}

Menurut Muysken selain penyisipan dan pergantian atau peralihan, ada jenis ketiga kode-pencampuran. Pada jenis yang ketiga ini terdapat beberapa fitur di antaranya terdapat unsur -unsur bahasa asing yang masuk dalam ujaran dan fitur yang kedua yaitu berupa kolokasi dan idiom.

Pada bentuk campur kode ini ditemukan bentuk campur kode multi konstituen. Ini dimungkinkan karena dua bahasa yang terlibat saling berbagi struktur sintaksis. Untuk itu peralihan dapat terjadi pada konstituen apapun. ${ }^{19}$

\section{Metode Penelitian}

\section{a. Metode Penyediaan Data dan Teknik-tekniknya}

Pada tahap tahap penyediaan data penelitimenggunakan dua metode yaitu

\footnotetext{
${ }^{18}$ Ibid, h. 23

${ }^{19}$ Ibid, h. 26
}

metode simak (pengamatan/observasi), dan metode cakap/wawancara. ${ }^{20}$ Pertama: Metode simak (Observasi/pengamatan) adalah metode pengumpulan data yang dilakukan dengan cara mengamati. ${ }^{21}$ Pada metode ini memiliki teknik dasar yaitu teknik sadap, Sebagai teknik dasar maka ia mengalami teknik lanjutan yaitu teknik simak bebas libat cakap, teknik simak libat cakap, catat, dan rekam. $^{22}$

Pada penelitin ini menggunakan metode simak dengan beberapa teknik yaitu Teknik simak bebas libat cakap (SBLC) disini peneliti menyadap perilaku berbahasa didalam suatu peristiwa tutur dengan tanpa keterlibatannya dalam peristiwa tutur tersebut. Jadi peneliti hanya sebagai pengamat. Dalam praktik penelitian teknik simak bebas libat cakap ini diikuti dengan teknik lanjutan berupa teknik catat dan dapat dibantu dengan teknik lanjutan yaitu teknik rekam. ${ }^{23}$ Adapun dalam penelitian di Pondok Madinah ini yang kedua menggunakan teknik simak libat cakap (SLC) atau disebut metode pengamatan berpartisipasi atau pengamatan penuh, yaitu dimaksudkan sebagai upaya penyadapan peristiwa tutur oleh peneliti dengan cara

${ }^{20}$ Mahsun, Metode Penelitian Bahasa Tahapan Strategi Metode Dan Tekniknya Edisi Revisi, (Jakarta:2012, Rajawali Press), h. 242-243

${ }^{21}$ Sudaryanto, Metode Dan Aneka Teknik Analisis Bahasa Pengantar Penelitian Wahana Kebudayaan Secara Linguistis, (Yogyakarta:1993, Duta Wacana Uneversity Press), h. 133.

${ }^{22}$ Mahsun, Metode Penelitian Bahasa Tahapan Strategi Metode Dan Tekniknya Edisi Revisi, (Jakarta:2012, Rajawali Press), h. 242

${ }^{23}$ Ibid, h. 243 
peneliti menyatu dengan partisipan yang hendak disimak perilaku tuturnya. ${ }^{24}$ Adapun langkah-langkah yang ditempuh oleh peneliti dalam penerapan teknik simak libat cakap ini pada dasarnya sama dengan langkah-langkah yang ditempuh dalam penerapan teknik simak bebas libat cakap yaitu disertai dengan teknik lanjutan berupa teknik catat dan teknik rekam. Kemudian sekembalinya dari penyediaan data, peneliti mempelajari catatan-catatan atau mentranskipkan rekamannya. ${ }^{25}$

Kedua: Kemudian metode yang kedua yaitu metode cakap (wawancara) dalam metode cakap diterapkan pertama-tama dengan pemancingan. Peneliti memancing informan agar berbicara. Informan adalah orang yang berfungsi sebagai nara sumber bahan penelitian, pemberi informasi dan pembantu sipeneliti dalam tahap pemerolehan data (kebahasaan) yang dicadangkan atau disediakan untuk dianalisis. ${ }^{26}$ Teknik pancing ini digunakan sebagai teknik dasar dan teknik rekam sebagai teknik lanjtan. Kemudian metode simak banyak digunakan teknik sadap sebagai teknik dasar, dan teknik catat serta teknik rekam sebagai teknik lanjutannya. Di samping itu juga diterakan konsep observer's paradox dari labov agar

\footnotetext{
${ }^{24}$ Ibid, h. 245

${ }^{25}$ Ibid, h. 246

${ }^{26}$ Tri Mastoyo Jati Kesuma, Pengantar Metode Penelitian Bahasa, Cet Pertama, (Yogyakarta:2007, Carasvatibooks) h. 42
}

didapatkan data yang senatural mungkin, yakni dengan melakukan penelitian terhadap informan dimana ia dibuat tidak sadar bahwa dirinya sedang diteliti. ${ }^{27}$

a) Metode Analisis Data

Analisis data dilaksanakan sesudah data terjaring diklasifikasikan. Klasifikasi data itu dilakukan sesuai dengan pokok persoalan yang diteliti. Yang perlu diperhatikan adalah hasil klasifikasi data itu harus memberikan manfaat dan kemudahan dalam pelaksanaan analisis data. $^{28}$

Langkah-langkah dalsam analisis data bahasa pada penelitian ini adalah sebagai berikut;

Memilah data berdasarkan jenis kontak bahasa (campur kode) kemudian Menganalisis faktor-faktor penggunaan bahasa. setelah itu semua data baik data bahasa maupun data pembelajaran bahasa arab dikumpulkan dan dianalisis, dalam hal ini peneliti menggunakan model interaktif mencakup empat komponen yang saling berkaitan, yaitu pengumpulan data, reduksi data, penyajian data, dan ksimpulan atau verifikasi. Sedangkan konseptualisasi, kategorisasi dan deskripsi dikembangkan atas dasar kejadian yang diperoleh ketika dilapangan. Karena kegiatan pengumpulan data dan analisis data menjadi satu kesatuan yang tidak dapat

\footnotetext{
${ }^{27}$ Kunjana Rahardi, Kajian Sosiolinguistik, (Bogor: 2010, Ghalia Indones Ia) h.12

${ }^{28}$ Tri Mastoyo Jati Kesuma, Pengantar Metode Penelitian Bahasa, Cet Pertama, (Yogyakarta:2007, Carasvatibooks) h. 47
} 
dipisahkan keduanya berjalan dengan simultan dan serempak. ${ }^{29}$

b) Sumber Data

Adapun sumber data utama dalam penelitian ini adalah santri Pondok Madinah, kemudian para guru, dan OPPM bagian bahasa, sumber data utama para santri, karena dari para santri objek penelitian ini berasal, yaitu berupa ujaran para santri yang menggunakan bahasa arab. Dalam penelitian ini, peneliti memilih tempat-tempat tertentu untuk dijadikan lokasi penelitian diantaranya adalah, di area asrama seperti di kamar sighar, kibar maupun depan kamar maupun, kemudian, di kamar mandi, di kelas, di koperasi, kantin, tempat makan.

Adapun sumber data lain yaitu para guru dan OPPM bagian bahasa, karena selain para guru, bagian bahasalah yang mengetahui secara utuh bagaimana penggunaan bahasa dikalangan para anggotanya dan menangani para santri secara langsung ketika mereka terlibat dalam pelanggaran bahasa dan ada juga salah seorang santri yang menjadi informan peneliti yaitu santriwati kelas V KMI, dia adalah santriwati yang menjadi ketua kamar, dengan demikian disini peneliti memintanya untuk menjadi informan dengan

${ }^{29}$ Muhammad Nur Kholis, Proses Alih Kode, Campur Kkode, dan Interferensi Dalam Percakapan Bahasa Arab Santri Studi Kasus Dipondok Pesantren Ta'mirul Islam, Yogyakarta: 2015, h. 22 memberikan informasi kebahasaan para anggotanya. Adapun sumber data pendukung adalah berupa dokumentasi yang berhubungan dengan tempat penelitian.

\section{Analisis Bentuk-Bentuk Campur Kode}

Muysken mengajukan 3 bentuk campur kode pertama; (insertion) penyisipan, kedua; (alternation) alternasi dan ketiga; (congruent lexicalization) leksikalisasi kongruen. ${ }^{30}$ Ketiga bentuk campur kode tersebut akan diuraikan secara terperinci berdasarkan fiturnya masing-masing. Pada bentuk campur kode penyisipan analisis akan diperinci dengan menjelaskan penyisipan konstituen tunggal, penyisipan konstituen ganda berdampingan dan penyisipan konstituen yang terintegrasi secara morfologis. Pada bentuk campur kode alternasi analisis akan diperinci dengan menjelaskan alternasi penandaan dan alternasi penggandaan. Sementara bentuk campur kode leksikalisasi kongruen analisis akan diperinci dengan menjelaskan unsurunsur bahasa asing yang masuk dalam leksikalisasi kongruen, dan peralihan pada kategori idiom.

Campur kode di kalangan santri pondok Madinah melibatkan beberapa bahasa. Adapun beberapa unsur-unsur leksikal bahasa yang sering masuk dalam percakapan bahasa Arab adalah bahasa Indonesia, Jawa dan Lampung. Hal ini

${ }^{30}$ Annisa Ramadhani, Campur Kode dalam Acara Welcome To Bca Di Metro Tv, Fib Ui, Jakarta: 2011, h. 14 
dikarenakan santri yang berlatarbelakang dari suku tersebut. Masuknya unsur-unsur leksikal bahasa asing ke dalam bahasa Arab sangat beragam, mulai dari penyisipan yang berupa kata, frasa dan klausa. Tetapi tidak hanya itu penelti juga banyak mendapatkan interjeksi berbahasa Jawa dan Indonesia dalam percakapan. seperti interjeksi yang berupa partikel kok, lah, eh, nganu, thok, wong dan masih banyak lagi. Penyisipan yang berupa partikel tersebut sudah akrab di telinga santri dan di rasa hal yang lazim, karena keterpengaruhan bahasa lokal yang kuat. Sebenarnya hal demikianlah yang menyebabkan percakapan bahasa Arab dikalangan santri Pondok Madinah terkesan kurang fasih.

Berdasarkan dari sejumlah peristiwa tutur yang berhasil dijangkau dalam penelitian ini, peneliti mendapatkan data rekaman komunikasi bahasa Arab santri yang didalamnya terdapat beberapa bentuk campur kode. Bentuk campur kode penyisipan, Jenis alternasi dan campur kode yang ketiga yaituleksikalisasi kongruens. Bentuk campur kode akan diidentifikasi berdasarkan fitur masingmasing dan dianalisis secara terperinci. Adapun uraiannya sebagai berikut:

\section{Insertion (Penyisipan)}

Unsur-unsur yang dimasukkan dalam bentuk campur kode penyisipan, adalah berupa konstituen, yang mana konstituen tersebut berupa unit sintaksis berbentuk kata dan frasa. Penyisipan yang memasukkan elemen tunggal disebut well-defined. ${ }^{31}$ Ada juga beberapa kasus yang memasukan beberapa konstituen dalam satu tuturan sehingga disebut penyisipan konstituen ganda berdampingan. Selain kedua fitur tersebut ada satu fitur lain yang masuk pada penyisipan, yaitu konstituen yang terintegrasi secara morfologis.

\section{a. Penyisipan Konstituen Tunggal}

Berikut ini akan diuraikan unsur-unsur Bahasa Jawa, Indonesia dan Lampung yang masuk dalam percakapan bahasa arab santri Pondok Madinah. Penyisipan kata dan frasa yang masuk dalam konstituen tunggal yaitu berupa adjektiva, adverbia, verba, pronomina atau kata ganti, numeralia, interjeksi Bahasa Indonesia dan bahasa Jawa, reduplikasi atau pengulanganBahasa Indonesia dan Jawa, dan frasa nomina.

" أنظر lho petakilan رجلك

//Rijluki lho petakilan unz\}ur//

Kakimu lho petakilan lihatlah!

Pada data campur kode nomer (1), terdapat penggalan percakapan bahasa Arab yang disisipi unsur bahasa Jawa yaitu "lho petakilan”. Satu konstituen kata yang disisipkan yaitu berlatarbelakang didalam asrama sighar konteksnya bercanda dengan teman satu kamar usai sekolah, santri melakukan

${ }^{31}$ Annisa Ramadhani, Campur Kode dalam Acara Welcome To Bca Di Metro Tv, Fib Ui, Jakarta: 2011, h. 21 
campur kode berupa penggalan ujaran adjektifa yaitu "petakilan". Penyisipan yang berupa konstituen kata tunggal, dalam bahasa Indonesia berarti "pecicilan" atau yang dimaksud penutur yaitu "tidak sopan" atau perilaku mitra tutur yang tidak sopan, penutur menyisipkan unsur bahasa Jawa karena ia tidak mengetahui padanan bahasa Arab yang sesuai. Sementara itu adanya penanda fatis yang berupa partikel untuk menguatkan tuturan "lho" yang berfungsi menandai perasaan heran campur terkejut atas suatu hal yang negatif. Kata "petakilan” merupakan adjektiva bahasa Indonesia dan dapat diubah menjadi غير مؤدب. Sementara penanda fatis "lho" yang menandai perasaan heran campur terkejut ini sebaiknya juga diubah kedalam ungkapan baasa Arab, karena di dalam bahasa Arab juga mengenal ungkapan-ungkapan sebagai penguat tuturan. Adapun ungkapanungkapan dalam bahasa Arab adalah sebagai berikut:

- مانشاءاله

- سبحان اله

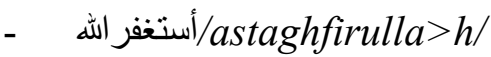

- مأفع /ma af'ala/

- أفعل به/af'il bih/

Ungkapan-ungkapan seperti diatas memiliki makna yang berbeda, سبحان dan اله /subha $>$ nalla $>$ h/sebagai ungkapan atas sesuatu yang positif, misalkan seperti mengagumi keindahan dan ciptaan Allah dan juga mengungkapkan rasa heran terhadap Suatu kejadian, ungkapan ستغفر اله lastaghfirulla $>$ h/untuk mengungkapkan keheranan atau suatu yang negatif atau keburukan atas perilaku seseorang. Ungkapan ماأفعل bih/dapat diterapkan pada kata-kata seperti contoh:

- ما أحسن العلم /ma> ah\}sana al-ilma/ betapa bagusnya ilmu (itu)

- ما مأقبح الجهل buruknya kebodohan (itu). ${ }^{32}$

Dengan demikian ungkapan bahasa Indonesia "Iho" dalam penggalan percakapan tersebut dapat dapat diubah kedalam ungkapan bahasa Arab menjadi ستغفر الله lastaghfirulla $>$ h/untuk menunjukkan keheranan atas perilaku buruk seseoang dan mengurangi ungkapan-ungkapan yang berupa interjeksi bahasa Indonesia maupun Jawa Sehingga percakapan bahasa Arab bisa lebih fasih.

\section{b. Penyisipan Konstituen Ganda Berdampingan}

Pada data percakapan campur kode Bahasa arab santri ditemukan $\checkmark$ penggalan percakapan yang masuk dalam kelompok penyisipan konstituen ganda berdampingan.

Di bawah ini akan diuraikan contoh penggalan ujaran yang disisipi lebih dari satu konstituen kata.

${ }^{32}$ Hisyam Zaini, Bahasa Arab Khas Gontor, Bunyan, Yogyakarta 2013, h. 117 
"nganu" في الليل مناقتشة حار جدًا "gila" .

هل جاز لنا أن نصلى فى مكان إنسان

نصر انى

gila fi $>$ allayli muna $>$ qosyah $h\} a>r$ jiddan nganu hal ja>za lana $>$ an nus\}olliya $f i$ maka $>n$ insa $>n$ nas $\}$ ro $>n i>$ ?

Gila diskusi tadi malam seru sekali, nganu bolehkah kita sholat di tempat orang nasrani?

Pada data campur kode nomer (1)yaitu berlatarbelakang didalam asrama kibar dengan konteks penutur dan lawan tutur sedang membahas tema diskusi yang diadakan rutin setiap hari kamis siang. Penutur melakukan campur kode dengan menyisipkankonstituen kata berdampingan yaitu pada kata "gila" dan "nganu". Kata gila merupakan interjeksi bahasa indonesia yang berupa ungkapan keheranan atau kekaguman. Sementara "nganu" merupakan penanda fatis Bahasa Jawa yang berupa kata. "nganu" dalam bahasa Indonesia tidak memiliki padanan yang sesuai, lebih tepatnya "nganu" sebuah ekspresi ragu-ragu, bingung atau ekspresi ketidak pastian dalam bahasa Jawa. Interjeksi "gila" merupakan unsur leksikal asing bahasa Indonesia yang masuk dalam kalimat bahasa Arab dapat diubah dengan interjeksi ungkapan bahasa Arab dengan ماثشاءالهةdan interjeksi “nganu”merupakan unsur leksikal asing yang tidak ada dalam bahasa Arab sehingga interjeksi tersebut tidak perlu dipakai dalam tuturan, atau dapat diganti dengan kosakata bahasa arab

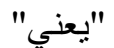

\section{c. Penyisipan Konstetuen Yang Terintegrasi Secara Morfologis}

Pada data percakapan campur kode di Pondok Madinah terdapat beberapa kasus percakapan bahasa arab yang terintegrasi secara morfologis dengan bahasa Indonesia, sehingga tuturan santri yang bebahasa arab memiliki struktur bahasa Indonesia. Adapun contoh kasus yang telah didapatkan oleh peneliti sebagai berikut:

1. في بيت أخي يلعب سياره سيار هن؟

$F i>y$ bayt akhi>y yal'ab sayya $>$ rohsayya $>$ rohan

Di rumah adiku main mobil-mobilan

Pada data campur kode nomer (1) terdapat penyisipan konstituen yang terintegrasi secara morfologis yaitu pada kata "sayya>roh-sayya>rohan" kelas kata nomina. pada kata tersebut memiliki arti mobilmobilan dalam bahasa indonesia, sementara kata"sayya>roh-sayya>rohan" secara gramatikal kurang tepat dalam struktur bahasa Arab, yang merupakan struktur Bahasa Indonesia, kata "sayya>roh-sayya $>$ rohan" mengalami reduplikasi pada kata "sayya>roh" dan afiksasi yaitu berupa sufik atau akhiran berupa "an". Kata sayya>roh sayya $>$ rohan dapat diubah dalam bahasa arab menjadi لعبة سيار ات.

\section{Alternation (Alternasi)}

Bentuk campur kode yang kedua adalah alternasi,dalam alternasi terjadi pera- 
lihan beberapa konstituen dalam satu ujaran karena penutur mengalihkan bahasa maupun ragam secara bersamaan. Muysken menyebutkan bahwa alternasi muncul ketika dua bahasa dapat digantikan fungsinya satu sama lain baik dari segi gramatikal maupun dari segi leksikalnya. ${ }^{33}$ bentuk seperti ini dapat disebut dengan alternasi. Alternasi memiliki dua fitur yaitu penandaan (flagging) dan penggandaan (doubling) yang akan diuraian sebagai berikut:

\section{a. Penandaan (flagging)}

Menurut Muysken pada fitur ini ditemukan fenomena penandaan yang menunjukkan bahwa akan ada bahasa lain yang akan diujarkan oleh penutur ${ }^{34}$. Seperti pada penggalan ujaran berikut:

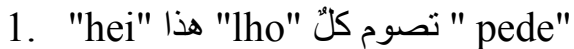

//hei haza\}> lho tas $\}$ u $>m$ kullun pede//

Hey ini lho semua puasa yee pede

Pada data campur kode nomer (1) yaitu berlatarbelakang didalam asrama kibar dengan konteks penutur memberitahu kepada lawan tutur bahwa teman satu kamar semuanya puasa. Pada penggalan tersebut terdapat ungkapan "hey" yang menjadi sebuah penanda bahasa Indonesia yaitu di awal tuturan. Dengan munculnya ungkapan "hey" di awal tuturan menandai bahwa akan ada

${ }^{33}$ Annisa Ramadhani, Campur Kode Dalam Acara Welcome To Bca di Metro Tv, Fib Ui, Jakarta: 2011, h. 23

${ }^{34} I b i d$, h. 50 ungkapan bahasa Arab yang akan muncul setelahnya. Kata "hey" berupa interjeksi bahasa Indonesia yang berfungsi sebagai panggilan, interjeksi tersebut dapat diubah kedalam interjeksi bahasa Arab dengan با . Interjeksi dalam bahasa arab disebut /harfu an-nida $\%$ Huruf nida' adalah suatu kata yang digunakan untuk memanggil atau memperingatkan sesuatu kepada seseorang atau kelompok untuk melaksanakan atau memperhatikannya. Interjeksi yang digunakan untuk memanggil dalam bahasa arab ada tujuh:

$$
\begin{array}{ll}
\text { /a/ } & \text { 'hai' } \\
\text { /ay/ } & \text { 'hai' } \\
\text { /ya/ } & \text { 'hai' } \\
\text { /a/ } & \text { 'hai' } \\
\text { /aya/ } & \text { 'hai' } \\
\text { /haya/ 'hai' }
\end{array}
$$

Huruf-huruf interjeksi ini dibagi menjadi empat kelompok yaitu:

1. Untuk memanggil sesuatu yang jauh digunakan /aya/, /haya/, dan /a/

2. Untuk memanggil sesuatu yang dekat digunakan dengan kata /ay/ dan /a/

3. Untuk memanggil yang dekat dan yang jau digunakan /ya/

4. Seruan untu menyatakan ratapan atau keluhan menggunakan $/ \mathrm{wa} /{ }^{35}$

Interjeksi yang terdapat pada tuturan tersebut dimaksudkan untuk menyeru meminta perhatian dan mengingatkan kepada

\footnotetext{
${ }^{35}$ Khairina Nasution, Interjeksi Dalam Bahasa Arab, Usu Repository, 2006, h. 15
} 
mitra tutur yang jaraknya berdekatan sehingga digunakan interjeksi dalam bahasa Arab dengan Lartinya 'hai'. Sementara "lho" yang berfungsi menandai perasaan heran campur terkejut ini sebaiknya juga diubah kedalam ungkapan bahasa Arab, karena di dalam bahasa Arab juga mengenal ungkapan-ungkapan sebagai penguat tuturan seperti dalam penjelasan data penggalan campur kode penyisipan konstituen tunggal nomer (1). Selainkedua interjeksi yang masuk dalam tuturan ada juga unsur lain yang masuk dalam tuturan yaitu "PD" merupakan frasa nomina kepanjangan dari "percaya diri" frasa nomina tersebut dapat diubah kedalam واثق النفس bahasa arab menjadi

\section{b. Penggandaan (doubling)}

Adapun contoh kasus campur kode penggandaan yang akan diuraikan sebagai berikut:

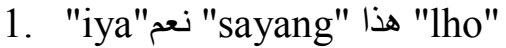

//iya na'am sayang haz> \}a lho//

iya iya sayang ini lho

Pada data campur kode no (1) yang berlatarbelakang di koperasi pelajar dengan konteks memberikan kue kepada mitra tuturr, dengan hati ikhlas. Bentuk adverbia na'am dalam Bahasa Arab memiliki arti "iya" sebenarnya sudah cukup, karena sudah menggunakan bahasa aresmi pondok (Bahasa Arab) tetapi justru didahului dengan kata "iya" yaitu bahasa indonesia. Meskipun itu sifatnya sebuah penekanan dalam sebuah tuturan seharusnya, santri tidak menambahkan bahasa indonesia, lebih baik menggunakan ungkapan bahasa arab.ungkapan-ungkapan sebagai penguat tuturan seperti dalam penjelasan data penggalan campur kode penyisipan konstituen tunggal nomer (1).

\section{Congruent Lexicalization (Leksikalisasi Kongruen)}

Menurut Muysken selain penyisipan dan pergantian, ada jenis ketiga kodepencampuran. Pada jenis yang ketiga ini terdapat beberapa fitur diantaranya terdapat unsur-unsur bahasa asing dan klausa yang masuk dalam ujaran dan fitur yang kedua yaitu berupa kolokasi dan idiom.

\section{a. Unsur-unsur bahasa asing yang masuk dalam leksikalisasi kongruen}

Pada bentuk campur kode ini ditemukan bentuk campur kode multikonstituen. Ini dimungkinkan karena bahasa yang terlibat saling berbagi struktur sintaksis. Untuk itu peralihan dapat terjadi pada konstituen apapun. ${ }^{36}$ Dalam kasus ini ditemukan sejumlah campur kode yang masuk dalam kategori leksikalisasi kongruen. Adapun contoh kasus akan diuraikan sebagai berikut.

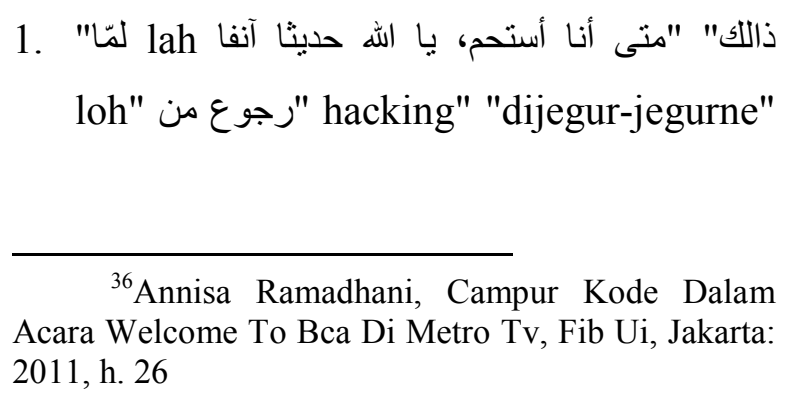

${ }^{36}$ Annisa Ramadhani, Campur Kode Dalam Acara Welcome To Bca Di Metro Tv, Fib Ui, Jakarta: 2011, h. 26 


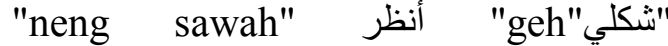

haa.خذائي وجهي غير واضح

//lamma $>$ lah mata $>$ ana $>$ astahim, ya Alla $>$ h hadi>tsan a>nifan dha>lik tho ruju>' min hacking dijegur-jegurne neng sawah unzjur geh syakliy> haa.. khiz $\mid a>$ iy wajhi $>$ y ghairu wa>zd\}ih//

Belum lah kapan aku mandi, ya Allah baru tadi itu lho pulang dari hacking dijegurne-jegurne neng sawah liat geh rupaku, haa... sepatuku wajahku enggak jelas.

Pada data campur kode nomer (1) terdapat penanda fatis berupa partikel "lah" dapat di uabah ke dalam ungkapan bahasa Arab menjadi ياأختيdan "lho" yang berfungsi menandai perasaan heran campur terkejut ini sebaiknya juga diubah kedalam ungkapan bahasa Arab, karena di dalam bahasa Arab juga mengenal ungkapan-ungkapan sebagai penguat tuturan seperti dalam penjelasan data penggalan campur kode penyisipan konstituen tunggal nomer (1). Sementara klausa "hacking dijegur-jegurne neng sawah" yang memiliki arti "hacking dicebur-ceburin ke sawah" kata "dijegurjegurne" merujuk ke tata bahasa Jawa merupakan verba ulang yang mengalami afiksasi yang berupa konfiks di- dan nepada kata "jegur" menjadi dijegur-jegurne dapat di ubah ke dalam ungkapan bahasa Arab yang sesuai menjadi تدخلني فى المزرع .

\section{b. Peralihan Pada Ketegori Idiom:}

Menurut Muysken terjadinya peralihan pada leksikalisasi kongruen dibolehkan atas semua kategori seperti kata tugas, kolokasi dan idiom. Kolokasi dan idiom adalah fitur akhir dari leksikalisasi kongruen. Adapun dalam contoh penggalan tersebut terdapat peralihan berupa idiom, Pada penelitian campur kode santri Pondok Madinah ditemukan satu kategori idiom seperti contoh penggalan berikut:

1. " المهم أنا رأي المنام عن ماذا hukum karma "

Almuhim ana $>$ ra' yul mana $>m$ 'an

ma>dha? "hukum karma"

Aku bermimpi tentang hukum karma.

Pada data campur kode nomer(1) bentuk yang dialihkan berupa idiom yaitu "hukum karma" yang apabila diterjemahkan dalam bahasa arab menjadi "النصيب"

\section{Kesimpulan}

Berdasarkan hasil penelitian studi kasus di Pondok Modern Madinah, maka dapat disimpulkan beberapa poin penting di antaranya adalah bentuk campur kode penyisipan, campur kode alternasi, dan campur kode leksikalisasi kongruen yang mana dari ketiga bentuk campur kode ini adalah teori yang diajukan Muysken. Campur kode pada penyisipan ini memiliki tiga fitur yaitu, pertama; penyisipan konstituen tunggal, kedua penyisipan konstituen ganda berdampingan, dan yang ketiga penyisipan yang terintegrasi secara morfologis.Alternasi 
memiliki dua fitur yaitu penandaan (flagging) dan penggandaan (doubling). Pada bentuk campur kode yang ketiga ditemukan bentuk campur kode multikonstituen. Ini dimungkinkan karena dua bahasa yang terlibat saling berbagi struktur sintaksis. Untuk itu peralihan dapat terjadi pada konstituen apapun.

\section{Daftar Pustaka}

Chaer, Abdul, 2007, Linguistik Umum Cet Ketiga, Jakarta, Rineka Cipta

Chaer, Abdul dan Leonie Agustina, 2004, Sosiolinguistik Perkenalan AwaL Edisi Revisi CetKedua, Jakarta, Rineka Cipta

Departemen Pendidikan Dan Kebudayaan, 1997, Kamus Besar Bahasa Indonesia (KBBI) Cet IX, Jakarta:, Balai Pustaka

Guntur Tarigan, Henry, 2009, Pengajaran Kedwibahasaan, Bandun:, Angkasa

Kridalaksana, Harimurti, 2001, Kamus Linguistik Edisi Ketiga, Jakarta: Gramedia Pustaka Utama

Mahsun, 2012, Metode Penelitian Bahasa Tahapan Strategi Metode Dan Tekniknya Edisi Revisi, Jakarta, Rajawali Press

Mastoyo Tri, 2007, Pengantar Metode Penelitian Bahasa, Cet Pertama, Yogyakarta:Carasvatibooks

Muhammad Nur Kholis, 2015, Proses Alih Kode, Campur Kkode, Dan Interferensi Dalam Percakapan Bahasa Arab Santri Studi Kasus Dipondok Pesantren Ta'mirul Islam, Yogyakarta
Muysken, Pieter, 2000, Bilingual Speech A Typology of Code Mixing, Cambridge University Press, Cambridge

Sumarsono, 2013, Sosiolinguistik, Yogyakarta: Pustaka Pelajar Sabda

Putu Wijana Dewa dan Muhammad Rohmadi, 2012, Sosiolinguistik Cetakan IV, Yogyakarta, Pustaka Pelajar

Rahardi, Kunjana, 2010, Kajian Sosiolinguistik, Bogor: Ghalia Indonesia

Sudaryanto, 1993, Metode Dan Aneka Teknik Analisis Bahasa Pengantar Penelitian Wahana Kebudayaan secara Linguistis, Yogyakarta, Duta Wacana Uneversity Press

Suwandi, Sarwiji, 2008, Serbalinguistik Mengupas Pelbagai Praktik Bahasa Cetakan I,. Surakarta: Lpp Uns dan Uns Press

Tesis oleh Ramadhani, annisa, 2011, Campur Kode Dalam Acara Welcome To BCA Di Metro TV, FIB UI, Jakarta

Zaini, Hisyam, 2013, Bahasa Arab Khas Gontor, Yogyakarta, Bunyan 
192 | Il-Fathin Vol. 1 Edisi Juli-Desember 2018 